\title{
Mental Health Issues Someone Who Has Divorce
}

\section{Andria Pragholapati}

Mental health is a state of well-being associated with happiness, joy, satisfaction, achievement, optimism, or hope. While mental disorders are behavioral or psychological patterns that are shown by individuals that cause distress, dysfunction, and reduce the quality of life (Stuart, 2013). Based on the Law of the Republic of Indonesia Number 18 Year 2014, mental health is a condition where an individual can develop physically, mentally, spiritually, and socially so that the individual is aware of his own abilities, can deal with stress, can work productively, and is able to contribute to the community.

People with Psychiatric Problems, hereinafter abbreviated as ODMK are people who have physical, mental, social, growth and development, and / or quality of life problems so that they are at risk of developing mental illness. People with mental disorders, hereinafter abbreviated as ODGJ are people who experience disturbances in thoughts, behaviors, and feelings that are manifested in the form of a set of symptoms and / or changes in meaningful behavior, and can cause suffering and obstacles in carrying out people's functions as human beings.

Stress on Someone Who Has Divorce

Lovibond \& Lovibond (1995) defines stress as an emotional response that arises due to pressing events in an individual's life. When someone stressed tends to become more irritable, it is difficult to calm down, and become impatient in dealing with various situations. Meanwhile, according to Stuart and Laraia (2007) stress is an adaptation model that can integrate biological, psychological and socio-cultural, environmental, legal and ethical factors.

Stress has been studied intensively as a depression factor (Zhang, 2013). This refers to physiological, emotional and cellular reactions. For example, emotional reactions include negative influences, dead emotional feelings and low positive affect. Stressor refers to trauma, life events, daily hassles / stress, hostile physical environment, role tension, and cumulative difficulties. The third component focuses on how stress is felt, including threats, hazards, losses, challenges, or benign, and the severity of stress (Aldwin, 2007 in Zhang, 2013).

Stimulus that is perceived by someone as a stressor, challenge, threat, or demand and which requires extra energy for coping is called Precipitating Stressors. Stress Precipitation consists of Nature, that is how an individual faces challenges / threats that come both from internal and external, Origin, that is the threat / challenge itself comes from the family itself, what is the environment, Timing is when the threat / challenge comes that can threaten the person, and Number, that is how many threats came to that person (Stuart, 2013).

Impact of stress According to Higgins (2001) explained that the impact of stress in outline there are two kinds, namely stress that has a positive impact, will be displayed in the form of increased work performance, stimulation of working to be more active, increased early motivation, increased inspiration for a better life and so. And negative impacts While the negative effects of stress, will occur if the Stressor exceeds the limits of the ability of individuals who cope. According to Potter and Perry (2005) stages of stress acceptance according to the 
range of loss responses according to Kubbler Ross, namely the stage of rejection (denial), angry (angry), bargaining (shaking), depression and acceptance (acceptance). If related to stress acceptance theory according to Kubler Ross, the results of this study show that respondents who have negative stress acceptance responses are at the stage of accepting stress (shaking) and depression. This study also shows that respondents who have positive stress acceptance responses are at the acceptance stage that is able to accept the stress they are experiencing. The acceptance stage (acceptance) of the respondent has reached the point of surrender and tries to accept the situation calmly, such as Kubler-Ross's theory which defines an attitude of acceptance when someone is able to face reality rather than just giving in to resignation or despair.

*Nursing Department, Universitas Pendidikan Indonesia Andria.pragholapati@upi.edu

\section{REFERENCES}

Ade, M.S., Tjutju, Pragholapati, A., 2016. GAMBARAN KUALITAS HIDUP PADA LANSIA DI BALAI PERLINDUNGAN SOSIAL TRESNA WERDHA CIPARAY BANDUNG TAHUN 2016.

http://ejurnal.stikesbhaktikencana.ac.id/file.php?file=preview_mahasiswa\&id=532\&cd=0b2173 ff6ad6a6fb09c95f6d50001df6\&name=JURNAL\%20SAKINAH\%202016.pdf.

Andria Pragholapati, M.L., 2017. HUBUNGAN MASALAH KESEHATAN JIWA DENGAN STRATEGI KOPING SESEORANG YANG MENGALAMI PERCERAIAN DI KOTA BANDUNG, in: Seminar Nasional Dan Workshop Keperawatan "Penguatan Profesi Keperawatan Dalam Peningkatan Pelayanan Keperawatan" Continuum of Care Dari Ketergantungan Menuju Kemandirian Hidup Yang Berkualitas. ISBN: 978-602-14422-8-9.

Andria Pragholapati, R., 2018. DEVELOPMENT OF THE INDONESIAN NATIONAL QUALIFICATIONS FRAMEWORK FOR NURSING CURRICULUM, in: International Conference on Education and Regional Development 3rd (ICERD) 2018 "Curriculum for Generation of Discruptive and 4th Industry Revolution Era." p. 44.

Andria Pragholapati, R.M., 2017. HUBUNGAN BULLYING DENGAN KEMAMPUAN SOSIAL PADA REMAJA DI SMK MVP KOTA BANDUNG TAHUN 2017, in: Konferensi Nasional Keperawatan Kesehatan Jiwa XIV Di Kalimantan Selatan Tahun 2017.

Andria Pragholapati, T., 2018. HUBUNGAN PENGGUNAAN SMARTPHONE DENGAN KUALITAS TIDUR PADA REMAJA DI SMK X BANDUNG, in: Konferensi Nasional Keperawatan Kesehatan Jiwa XV Di Hotel Four Point By Sheraton Makassar Sulawesi Selatan. pp. 1-7.

Ardiana, F., Nurlianawati, L., Pragholapati, A., 2016. Gambaran Fungsi Kognitif Pada Lanjut Usia (Lansia) Di Panti Jompo Muhammadiyah dan Yayasan Pondok Lansia Tulus kasih. 
Ariani, A., Pragholapati, A., Pratama, A.S., 2020. Information Communication Technology (ICT) In Midwifery Education: A Review of the Literature, in: The 3rd International Seminar on Global Health (ISGH) "Technology Transformation in Health Care for Better Life" Bandung, West Java, Indonesia. http://repository2.stikesayani.ac.id/index.php/isgh3/article/view/352, pp. 66-69. Ismawati, Y., Pragholapati, A., 2020. KEJADIAN GASTRITIS DI DESA CINUNUK WILAYAH KERJA PUSKESMAS CINUNUK KABUPATEN BANDUNG.

Ismawati, Y., Sumbara, Pragholapati, A., 2018. HUBUNGAN POLA MAKAN DENGAN KEJADIAN GASTRITIS DI DESA CINUNUK WILAYAH KERJA PUSKESMAS CINUNUK KABUPATEN BANDUNG.

Pragholapati, A., 2020. Self-Efficacy Of Nurses During The Pandemic Covid-19.

Pragholapati, A., 2020. COVID-19 IMPACT ON STUDENTS. osf.io.

Pragholapati, A., 2020. RESILIENSI PADA KONDISI WABAH COVID-19.

Pragholapati, A., 2020. STRES KERJA PERAWAT YANG BEKERJA DI UNIT GAWAT DARURAT (UGD) RUMAH SAKIT AL ISLAM (RSAI) BANDUNG.

Pragholapati, A., 2020. MOTIVASI KERJA PERAWAT DI RUANG RAWAT INAP RSUD MAJALAYA KABUPATEN BANDUNG.

Pragholapati, A., 2020. MENTAL HEALTH IN PANDEMIC COVID-19.

Pragholapati, A., 2020. RESILIENSI PERAWAT YANG BEKERJA DI UNIT GAWAT DARURAT (UGD) RUMAH SAKIT AL ISLAM (RSAI) BANDUNG.

Pragholapati, A., 2020. NEW NORMAL “INDONESIA” AFTER COVID-19 PANDEMIC.

Pragholapati, A., 2019. THE EFFECT OF BRAIN GYM TO THE LEVEL OF DEPRESSION IN GERIATRIC AT BALAI PERLINDUNGAN SOSIAL TRESNA WERDHA CIPARAY BANDUNG. J. Sk. Keperawatan 5, 128-146.

Pragholapati, A., Munawaroh, F., 2020. RESILIENSI PADA LANSIA. J. Surya Muda 2, 1-8.

Pragholapati, A., Ulfitri, W., 2019. Gambaran Mekanisme Coping pada Mahasiswa Program Studi Sarjana Keperawatan Tingkat IV yang Sedang Menghadapi Tugas Akhir di Sekolah Tinggi IImu Kesehatan X Bandung. Humanit. J. Psikol. 3, 115-126.

Prasetyo M, D., Nurlianawati, L., Pragholapati, A., 2017. GAMBARAN TINGKAT KECEMASAN PADA PASIEN PRE OPERASI FIBROADENOMA MAMMAE DI RUANG GUNTUR RUMAH SAKIT TK II DUSTIRA CIMAHI TAHUN 2017.

http://ejurnal.stikesbhaktikencana.ac.id/mahasiswa.php?detail=mahasiswa\&id .... 
Rahmawati, S.D., Mulyati, T., Pragholapati, A., 2015. HUBUNGAN BODY IMAGE DENGAN POLA DIET PADA REMAJA PUTRI DI SMAN 24 BANDUNG TAHUN 2015.

http://ejurnal.stikesbhaktikencana.ac.id/file.php?file=preview_mahasiswa\&id ....

Rosmala, I., Jundiah, S., Pragholapati, A., 2017. TINGKAT KECEMASAN PADA KELUARGA PASIEN DI RUANG ICU RSUD MAJALAYA KABUPATEN BANDUNG TAHUN 2017.

http://ejurnal.stikesbhaktikencana.ac.id/file.php?file=preview_mahasiswa\&id=517\&cd=0b2173 ff6ad6a6fb09c95f6d50001df6\&name=Jurnal\%20Imas\%20Rosmala\%202017.pdf.

Septriani, D., Sari, Y.R., Pragholapati, A., 2019. The Relationship of Social Support With the Anxiety Level of Parents of Children with Thalassemia of Pre-School Age that Works in the Activities of Blood Transfusion in Hospital " $X$ " Bandung, in: The 2nd Bandung International Conference on Collaborative Health Research Research. Prama Grand Preanger Hotel Bandung, West Java, Indonesia 7th - 8th of October 2019. p. 12.

Virgona, A., Pragholapati, A., 2019. Enhancing Critical Thinking Skills in Nursing Higher Education in Preparation for the Industrial Revolution 4.0: Literature Review, in: The 3rd International Seminar on Global Health (ISGH) "Technology Transformation in Health Care for Better Life" Bandung, West Java, Indonesia. 